\title{
CRÍQUETE E NACIONALISMO HINDU NA ÍNDIA: ILUSÕES DA INTERPRETAÇÃO TEXTUAL ${ }^{1}$
}

\author{
Nissim Mannathukkaren \\ Dalhousie University, Halifax, Nova Scotia, Canada
}

\section{Resumo:}

Este artigo apresentará uma crítica da tentativa da teoria pós-colonial em ler o nacionalismo no críquete exibido no filme de Bollywood, Lagaan, que foi indicado ao Oscar. Esse filme contesta a missão civilizatória do colonialismo britânico e também restaura a agência das classes subalternas. Diferente disso, este trabalho argumenta que o nacionalismo no críquete reproduz o nacionalismo burguês indiano, que não tem lugar para o subalterno. Também argumenta que a tese pós-colonial de descolonização e indigenização do críquete supostamente realizada por Lagaan é marcada por um culturalismo que não considera fatores estruturais como capital, classe e casta que dominam a instituição do críquete na Índia. Por fim, contra a tendência da teoria pós-colonial em ler os textos de forma isolada do contexto, afirma-se que o nacionalismo do críquete no filme pode ser entendido ao localizá-lo em relação à atual suposição onde as forças de capital e o nacionalismo são hegemônicos.

Palavras-chave: Esporte. Nacionalismo. História; Índia.

\section{Introdução}

O fascismo vê sua salvação ao proporcionar a essas pessoas não apenas seus direitos, mas a chance de se expressar. Essas pessoas têm o direito de alterar as relações de suas propriedades. $\mathrm{O}$ fascismo procura proporcionar a eles uma expressão ao mesmo tempo em que mantém suas propriedades. O resultado lógico do fascismo é a inserção da estética na vida política. (BENJAMIN, 1955, p. 241)

1-Publicado originalmente no International Journal of the History of Sport, vol. 24, n. 9, p. 1200-1225, September 2007. Traduzido com autorização do autor pelo Centro de Excelência Empresarial Ltda-Me (Cetur). Revisão: Cleber Dias. 
Desde o surgimento da teoria pós-colonial, houve uma verdadeira explosão de interesse por fenômenos como o "colonialismo" e a "descolonização". É natural, portanto, que o jogo do críquete, um dos últimos legados do Império britânico, seja objeto de estudo entre os teóricos nas antigas colônias britânicas. Como o jogo se tornou "popular" e "indigenizado", ou em que medida ele se transformou num meio para impulsionar a empresa colonial ou para disseminar o nacionalismo são algumas das questões que têm animado os teóricos (ver APPADURAUI, 1995; NANDY, 1989). Recentemente, debates semelhantes surgiram sobre a natureza do críquete representado no famoso filme de Bollywood, Lagaan, que não é apenas sucesso de bilheteria na Índia, mas também atraiu atenção internacional devido a uma indicação ao Oscar. Uma das tentativas de entender o nacionalismo no críquete em Lagaan foi exibida por meio da teoria pós-colonial, mais especificamente, em projetos de estudos subalternos na Índia, uma das defensoras influentes da teoria pós-colonial (CHAKRABORTY, 2004; 2003). Ao debater criticamente esse assunto por meio desse artigo, proponho uma leitura alternativa que, por sua vez, analisará a questão da eficácia da teoria pós-colonial para entender a descolonização em relação ao críquete.

Com a ascensão da teoria pós-colonial (sob influência do pós-modernismo e do pós-estruturalismo), houve uma concentração intensa em conceitos como a "cultura", o "idioma", os "textos" e o "discurso". Enquanto isto não era uma tendência indesejada em si mesmo, problematicamente, a tendência predominante na teoria pós-colonial, tem sido a de reduzir os processos e as práticas sociais e históricas a meros textos e discursos. Há uma total "falta de analogia entre os textos e as instituições [...] e a consequente incapacidade de dar importância adequada às instituições" (DEWS, 1987, p. 35). Essa evasão da realidade não textual resulta em uma posição semelhante à afirmação "il n'y a pas de hors-text" - não há nada fora do texto. Uma vez que os significantes não têm qualquer significado fora do texto, somos forçados a construir "significados", se é que podemos chamá-los assim, para a cadeia infinita de seus próprios significantes. Essa é a área onde problemas materiais são transformados em problemas metafóricos (DIRLIK, 1997, p. 79).

Como Rosalind O'Hanlon e David Washbrook (1992, p. 145) observaram sobre as soluções pós-coloniais, 
o individualismo metodológico, o isolamento da despolitização do domínio social para o material, uma análise das relações sociais que, na prática, é extremamente voluntária, a recusa de qualquer tipo de política programática, não parecem tão radicais, subversivos ou emancipatórios. Eles são, na verdade, conservadores e implicitamente autoritários.

Chakroborty (2004, p. 551) faz duas importantes observações em relação à Lagaan: primeiro, em Lagaan há uma recuperação da "agência de classes subalternas e uma subversão da missão civilizatória do Império britânico por meio de [sua] representação do críquete na colônia". Isso ocorre por meio de dispositivos como o "mimetismo" e por meio da "vernacularização" e "indigenização" do críquete colonial. Em segundo lugar, "o cinema popular da Índia, principalmente Lagaan, apresenta o projeto dos estudos subalternos no meio visual" e não apenas "pode, efetivamente, descolonizar a imaginação do povo indiano", mas também, "por meio de filmes, como Lagaan", revelar "sua capacidade de incentivar as pessoas que ficam quietas, são esquecidas ou marginalizadas nos discursos dominantes" (CHAKRABORTY, 2004, p. 551-552).

Esse artigo questionará todas essas observações. Na primeira seção, tentarei demonstrar que a tentativa para entender Lagaan por meio de projetos subalternos apresenta falhas. Também apresentarei, em vez de recuperar a agência de classes subalternas, que o nacionalismo no críquete que surge em Lagaan é fortemente semelhante ao nacionalismo burguês da Índia em suas diferentes formas, desde o nacionalismo de Gandhi ao nacionalismo hindu atual, que não deixa lugar para os subalternos. Na segunda seção, analisarei as hierarquias que dominam a instituição do críquete na Índia para destacar as falhas da teoria pós-colonial de Chakraborty, que se refere à descolonização e à vernacularização apenas em termos culturais, sem mencionar a questão da democratização do jogo. Na última seção, contra a tendência de Chakraborty de ler o texto sem considerar o contexto, explicarei o contexto histórico, social e linguístico em que o filme Lagaan está inserido. Ficará claro ao final da discussão que o empoderamento das pessoas mencionadas no filme é uma noção vaga, que não tem conexão com a realidade material. 


\section{Excluindo o subalterno}

Chakraborty afirma que "o apelo do filme aos espectadores é incentivado pela construção do enredo de Lagaan sobre os camponeses afetados pela seca e pela apresentação de terras secas". Isso ocorreu porque o filme foi lançado na época em que a seca dominou gravemente as regiões ocidentais da Índia ${ }^{2}$. A condição do campesinato no filme é parecida com as condições reais dos camponeses, levando-os à empatia com o conteúdo do filme, que exibe um povo marginalizado superando todas as adversidades ${ }^{3}$. Além disso, ao apresentar camponeses subalternos não apenas jogando críquete, um jogo de elite, mas também ganhando a partida contra seus senhores coloniais, o filme produz uma nova "história, inscreve os despossuídos da periferia colonial [...] na história de um esporte popular" (CHAKRABORTY, 2004, p. 552-553). Supostamente, é aí que as semelhanças entre o filme e o projeto dos estudos subalternos surgem devido à tentativa de escrever uma história do ponto de vista subalterno e recuperar as ideias marginalizadas deles e delas. Ranajit Guha, o pai fundador do projeto dos estudos subalternos, criou a teoria de que uma nova forma de escrever a história era tão essencial quanto a historiografia do nacionalismo indiano, que até o momento era denominada pelo "elitismo - elitismo colonial e elitismo nacionalista burguês". Se a historiografia colonial reduziu a história do nacionalismo indiano aos esforços das "regras coloniais britânicas, administração, política, instituições e cultura", na versão nacionalista estava "escrito como um tipo de biografia espiritu-

2-O autor discute "as consequências desastrosas" da seca, como se fossem apenas fenômenos "naturais". Não menciona o papel (principal) da classe exploradora por parte do estado e como foram causadas.

3-Existe uma ânsia por parte de Chakraborty para estabelecer o sucesso do filme na esfera popular. Ela alega que o filme é um "sucesso fenomenal" nos "círculos de elite e de subalternos" (CHAKRABORTY, 2004, p. 565), sem apresentar quaisquer fatos ou números. O filme é apenas um "super-hit" feito pelos padrões da indústria de Bollywood - "super-hit" se encontra abaixo das categorias de "blockbuster" e "todos os hits ao longo do tempo". É apenas o sétimo maior hit nos últimos quatro anos. Nem sequer aparece entre os primeiros 200 filmes (em números atualizados) desde 1950 (todos os dados sobre os ingressos são da International Business Overview Standard Network, disponível em http://www.ibosnetwork.com/default.asp. Acesso em 9 nov. 2004).

Pensar a Prática, Goiânia, v. 15, n. 1, p. 1-271, jan./mar. 2012

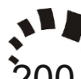


al da elite indiana". Por outro lado, o objetivo do projeto dos estudos subalternos era escrever uma história que trouxesse "a contribuição feita pelas próprias pessoas, que independe de a elite criar e desenvolver o nacionalismo indiano" (GUHA, 1982, p. 1-3). A historiografia marxista também passou por críticas destrutivas de [teóricos] subalternos por seu alegado reducionismo de classes, não entendendo as únicas formas de resistência subalterna sob o colonialismo (CHAKRABARTY, 1995).

A defesa do projeto dos estudos subalternos de Chakraborty e sua extensão ao entendimento de Lagaan são altamente problemáticas porque não aponta as complexas idas e vindas pelas quais o projeto tem passado. Assumindo que o problema central do projeto ainda é o mesmo durante duas décadas de sua existência, a autora ignorou a mudança drástica nas estruturas epistemológicas e teóricas desse projeto. Com isso, seu artigo também faz parte de evasões, exclusões e contradições que marcam os escritos das histórias subalternas. A estrutura teórica que Chakraborty utiliza é aquela dos estudos subalternos, que é fortemente culturalista e que abandonou totalmente o principal objetivo inicial de Gramsci. Ela ignora os escritos anteriores ou, quando se refere a eles, os deturpa totalmente.

Nada demonstra melhor o deslocamento na ênfase dos teóricos subalternos de Gramsci, Hobsbawm e E. P. Thompson para Foucault, Derrida e Said que os escritos de Partha Chatterjee sobre o nacionalismo (umas das figuras mais proeminentes dos estudos subalternos). A partir de uma postura semelhante à de Guha, conforme vimos acima, que fala sobre a profunda cumplicidade da elite nacionalista em silenciar os subalternos e da "falha da burguesia indiana de falar por sua nação" (GUHA, 1982, p. 5), Chatterjee (1993) se refere a uma teoria que, ao menos parcialmente, resgata a elite nacionalista da era colonial (ver também BANNERJI, 2000). O argumento agora é que o nacionalismo não pode ser visto como um movimento político apenas e o que é importante para o nacionalismo anticolonial é seu componente cultural e espiritual. Para Chatterjee, o nacionalismo da elite na era colonial já estabelece sua soberania no domínio espiritual antes mesmo de começar a luta pela soberania política. Se no domínio material o nacionalismo anticolonial não tem opção a não ser copiar os diversos modelos do nacionalismo do Ocidente, é no domínio cultural e espiritual que foi lançado seu 
mais poderoso, criativo e historicamente significativo projeto: o de adaptar a cultura nacional "moderna" que definitivamente não é do Ocidente. Se a nação é uma comunidade imaginada, é aí que tudo deve acontecer. Em seu domínio fundamental e verdadeiro, a nação já é soberana mesmo quando o estado está nas mãos do poder colonial. (CHATTERJEE, 1993, p. 6)

Linguagem, arte e estética, educação e constituição da família são, para Chatterjee, o "domínio interno da cultura nacional". A diferença entre os domínios cultural e material que Chatterjee assume são altamente problemáticas, pois os divide artificialmente. Ele não considera as formas complexas e dialéticas em que esses dois domínios interagem e são constituídos. Essa posição acredita que a descolonização pode ser realizada no domínio cultural sem uma descolonização correspondente nas esferas política e econômica. As figuras e o tropos dominantes da teoria pós-colonial estão agora lentamente sendo erigidos: "a cultura", "a diferença", "o espiritual" etc. É relevante aqui anotar que Chatterjee escolhe apontar o domínio cultural como o domínio verdadeiro e essencial. Sumit Sarkar argumenta sobre as mudanças teóricas dos estudos subalternos:

O que começou como uma falta de satisfação compreensível com o reducionismo economicista do Marxismo "oficial", hoje contribui para outro tipo de limite de horizontes e combina a exploração colonial com o domínio cultural ocidental. A análise do discurso colonial se exclui da história da produção das relações sociais, exceto em termos gerais. Um "culturalismo" mais enfraquecido nas leituras dos textos isolados se tornou, após a previsível morte do Marxismo, extremamente tenso em todas as histórias "materiais": o espectro do reducionismo econômico está presente em todos os lugares. (BANNERJI, 2000, p. 903)

Argumentarei, como veremos brevemente, que essa ruptura regressiva do cultural a partir dos processos materiais que caracterizam os últimos estudos subalternos também está presente no artigo de Chakraborty. Descolonização é algo que está primeiramente compreendido em termos discursivos e culturais. A questão crucial da descolonização interna não é direcionada a todos.

Outra mudança importante e relacionada aos deslocamentos dos 
estudos subalternos, crescentemente influenciados pelo pós-estruturalismo, é o afastamento da modernidade. Iluminismo ocidental e eurocentrismo se tornaram os novos objetos de crítica. Assim, o Estado, a sociedade civil, os direitos individuais, etc. são produtos do Iluminismo ocidental impostos pelo colonialismo, que são totalmente estranhos às sociedades que não fazem parte do Ocidente. O que pode resistir ao regime disciplinar, às instituições civis e sociais e à narrativa do capital é a narrativa da comunidade. É nessa hora que a imagem de Gandhi e sua retórica "antimodernista, anti-individualista" de "amor, parentesco, austeridade, sacrifício" se torna o símbolo de luta para a soberania do domínio interno (CHATTERJEE, 1993, p. 220239). A redenção de Gandhi nos últimos escritos subalternos vai contra sua incisiva crítica inicial à natureza da elite burguesa. Chakraborty faz comentários sobre isso e também sobre o movimento dos subalternos de rejeição a todos os tipos de nacionalismos para "um certo tipo de nacionalismo [cultural] que evita a modernidade" (BANNERJI, 2000, p. 904).

Por fim, uma mudança ainda mais importante que caracteriza os estudos subalternos é o abandono terrível do foco do subalterno em si. Em vez disso, o foco começa a ficar em assuntos como a classe média de Bengali, prisões coloniais, a nação, a comunidade, o idioma e a religião na Índia (BAHL, 2000, p. 91). Como Ramachandra, Guha observa em uma análise no volume 8 dos Estudos Subalternos: "Com o passar dos anos, a maioria dos membros do coletivo editorial trocou a documentação da oposição subalterna para a oposição do discurso da elite, da escrita com paixão (Socialista) para a seguinte adaptação (pós-modernista)" (GUHA, 1995, p. 2057). Sem perceber essa momentânea mudança, é difícil afirmar que Lagaan esteja se aprofundando no projeto dos estudos subalternos como Chakraborty faz.

Chakraborty argumenta que a caracterização dos camponeses no filme contraria os estereótipos da historiografia colonialista e nacionalista em que os camponeses eram vistos como ignorantes, egoístas e precisavam de liderança vinda de fora para se organizarem. Isso ocorre porque os camponeses identificavam os "oficiais ingleses como os 'inimigos verdadeiros', e não como reis" (CHAKRABORTY, 2004, p. 555). Ao contrário dessa afirmação, argumentei antes que aqui acontece o momento que define o filme, quando os camponeses são relacionados a um nacionalismo de elite. Ao identificar os oficiais ingleses como os "verdadeiros inimigos", o filme omite o papel dos príncipes 
nativos, dos reis feudais e dos colaboradores do Rajá britânico na opressão dos camponeses. Esta é uma ação típica do nacionalismo burguês por meio do qual todas as relações exploradoras dentro da nação são apagadas para colocar o inimigo fora da nação, neste caso, o colonizador branco; o outro racial $1^{4}$.

O nacionalismo no críquete mostrado no filme meramente reproduz esse nacionalismo burguês. Eu também argumentei que este momento de identificação do inimigo verdadeiro no filme foi muito semelhante ao conselho de Gandhi aos camponeses de Awadh, em 1921, para absolver os senhores feudais de quaisquer crimes praticados contra eles por estes serem escravos dos britânicos (isto foi um reflexo da estratégia da Frente Unida para subestimar a opressão de casta e de classes até conseguir a independência da nação - MANNATHUKKAREN, 2001). O que Chakraborty falha em reconhecer é que essa estratégia nacionalista da Frente Unida adquiriu uma forte fama entre as elites dominantes no presente, que a utilizam para sustentar sua legitimidade desgastada ao mencionar a ameaça de que a nação se depara com entidades transnacionais e subnacionais.

É realmente incompreensível que Chakraborty pudesse postular o momento em que os camponeses reduzem a opressão multifacetada para uma opressão simples - o Estado britânico - como um sinal de sua agência e subjetividade. A gigantesca escala de exploração dos senhores feudais que fez com que Jawaharlal Nehru ${ }^{5}$ a descrevesse como "completos parasitas da terra e de pessoas" (PANDEY, 1982, p. 161) não é citada no filme. Somente Chakraborty argumenta que o governante local é representado como "um governante fraco e ineficiente" que não cuida dos britânicos e que também "é oprimido pelo estado colonial no filme [!]" (CHAKRABORTY, 2004, p. 557-558).

Deixando de lado o princípio fundamental de escrever uma história crítica, ela assume os fundamentos do filme ao invés de questioná-los. Criticando minha postura de que o "outro" no filme é definido como

4-Isso não significa que os nacionalismos burgueses não podem visar um inimigo interno, principalmente as minorias étnicas e linguísticas - a Alemanha nazista é o pior exemplo e o nacionalismo hindu na Índia é um exemplo contemporâneo.

5-Nota do Revisor (NR): Jawaharlal Nehru foi um dos líderes do movimento nacionalista pela independência indiana. Em 1947, Nehru foi o primeiro político a ser eleito como Primeiro-Ministro da Índia independente.

Pensar a Prática, Goiânia, v. 15, n. 1, p. 1-271, jan./mar. 2012

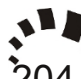


pertencente a outra nação, ela argumenta que existem "camadas de alteridade no filme" (CHAKRABORTY, 2004, p. 555). Porém, não é apresentado como essas camadas questionam a regra social dominante (tanto no período apresentado no filme, quanto nos dias de hoje), considerando que o filme é o mediador de projetos dos estudos subalternos. A única anormalidade superficial e de pouca importância na unidade sintética do espaço do vilarejo é apresentada quando o povo do vilarejo questiona a inclusão de Kachra, que pertence à casta "intocável", na equipe de críquete formada para jogar contra os britânicos. Outras discordâncias ocorrem quando Lakha, um aldeão hindu, tenta impedir Ismail, muçulmano, de fazer parte da equipe ao sugerir que os hindus não o aceitem. A preocupação entre os moradores da vila sobre a inclusão dos "intocáveis" foi facilmente resolvida quando o herói os convence ao afirmar que o rei hindu Rama condenou a intocabilidade. Chakraborty não percebe as implicações desse momento crucial no filme. Ela casualmente comenta: "O herói articulado conveniente e temporariamente resolve a resistência [dos aldeões] ao referir-se à mitologia hindu". A versão peculiar da mitologia que o herói expõe como sendo uma questão bramânica de casta superior não é percebida pela autora. O movimento dalit na Índia (as antigas castas intocáveis) é fortemente oposto a tais versões que apagam a natureza opressora do hinduísmo bramânico e que o apresenta como benigno e benevolente. Novamente, seguindo acriticamente as suposições do filme como um senso-comum, Chakraborty nega a história contra-hegemônica dos $d a$ lits. Aqui deve ser notado que Kancha Ilaiah, ativista dalit proeminente e culto, escreve que até mesmo os estudos subalternos coletivos não podiam incorporar a perspectiva dalit na escrita história indiana (ILAIAH, 1995).

Mesmo que os intocáveis fossem integrados ao time e contribuíssem para a vitória, não tinham falas importantes no filme. Como Siriyavan Anand (2004) observa na incisiva crítica dalit do filme:

Os subalternos não podem falar. Fora do jogo, Kachra (que em híndi ${ }^{6}$ também significa resíduo ou lixo) tem de seguir as palavras da casta hindu de Bhuvan. Ele nunca tem escolha. Kachra,

6-NR: Oficialmente, a Índia reconhece 22 idiomas como oficiais, com cada estado podendo eleger sua própria língua oficial. No entanto, o híndi, uma das principais e mais faladas línguas, foi adotado como língua oficial por mais de 10 estados.

Pensar a Prática, Goiânia, v. 15, n. 1, p. 1-271, jan./mar. 2012

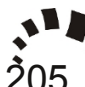


indivíduo excluído de qualquer aspecto social, cultural ou religioso do vilarejo, nunca pode opinar sobre participar ou não do jogo. Não fica claro se o dalit, apresentado pateticamente, está ciente do motivo do jogo ${ }^{7}$.

Chakraborty é forçada a afirmar que a representação do dalit é marcada por "servidão e silêncio" e a inclusão dele na equipe de críquete não altera o sistema social amplamente infestado por castas. Ainda assim, ela não percebe nada de errado na representação, uma vez que "indica os modos de improvisação da política dos camponeses, já que a juventude intocável pode fazer parte da equipe de críquete devido à sua excepcional habilidade em correr, o que poderia potencialmente facilitar a vitória para Champaner"8 (CHAKRABORTY, 2004, p. 557). Portanto, a inclusão dos intocáveis é uma tática útil com o único objetivo de ganhar a partida. Após esse fato, a situação comum voltará ao normal, e os intocáveis continuarão sua rotina de existência subumana ${ }^{9}$. Há diferença entre a manipulação do Partido do Congresso pós-independência dos dalit por meio das políticas corporativistas de banco de votos e as recentes tentativas desesperadas do BJP ${ }^{10}$ para privá-los da equipe hindu? Do ponto de vista de Ilaiah (1995, p. 165-166), o que o simbolismo e a cooptação fazem é se apropriar dos dalit como "hindus arruinados" e, no processo, eliminar sua identidade não hindu e sua cultura, idioma e filosofias separadas. A política de casta no filme pode ser vista como a continuação da

7-Nota do editor do Internacional Journal of the History of Sport (NE): Para esclarecer, Nissim está errado. Kachra tinha alguns diálogos no filme. Mas, como Anand salienta com razão, isso não representa qualquer afirmação do eu.

8-NR: Champaner é o local onde se desenrola o enredo do filme.

9-Isto é muito parecido com as tentativas do governo nacionalista hindu da direita, sob o Partido Bharatiya Janata, para se apropriar dos jogadores de cricket muçulmanos, como Irfan Pathan e Kaif Mohammad, como os "bons muçulmanos" e "ícones nacionais", enquanto ao mesmo tempo, cometem genocídio comunal no estado de Gujarat, que matou mais de 2.000 muçulmanos.

10-NR: BJP é a sigla de Bharatiya Janata Party, Partido do Povo Indiano, um dos maiores da Índia, ao lado, justamente, do Partido do Congresso. Criado em 1980, ideologicamente, o BJP tem se caracterizado pela defesa do nacionalismo hindu.

Pensar a Prática, Goiânia, v. 15, n. 1, p. 1-271, jan./mar. 2012 
apropriação bramânica da resistência contra-hegemônica através dos séculos (LELE, 1995). Chakraborty, ao confirmar a premissa do filme, participa dela.

A autora afirma que a hierarquia de relações sociais está evidente desde a "descrição das disparidades econômicas entre os camponeses donos de terras com diversas fazendas", até as dúvidas que existem sobre a inclusão do intocável e do muçulmano, passando pela total exclusão das mulheres na equipe de críquete (CHAKRABORTY, 2004, p. 556). O primeiro exemplo é uma hipótese da autora: não existe cena no filme que retrate categoricamente camponeses com diversas terras $^{11}$. Num argumento enganador, a autora acredita que mostrar posições sociais e de classe é um movimento revolucionário. Por este critério, todo filme de Bollywood deve ter as seguintes qualificações: em cada um, o herói pertence a uma casta superior, as mulheres estão sempre numa posição subordinada e existirão, claro, criados e membros da classe trabalhadora ${ }^{12}$.

A ordem social em Lagaan é representada como "natural". Nenhuma hierarquia é questionada, exceto em relação ao oficial inglês. As mulheres são totalmente felizes: cantam, dançam e cozinham para os homens. A exclusão da equipe de críquete não as incomoda. Essa atitude é aceita como algo "natural". Até mesmo as dúvidas sobre os intocáveis são expressas por pessoas da casta superior do vilarejo, e, como vemos, eles não falam. Também não existem outros intocáveis no filme. A identidade de casta de qualquer outra pessoa da vila também é desconhecida.

Estudos acadêmicos têm mostrado que a Índia rural na era colonial era caracterizada pela "opressão tridentina" de "sarkar, zamindar, sahukar" (Estado, proprietário, agiota) (SATHYAMURTHY, 1990, p. 109). Lagaan não aparenta reconhecer qualquer opressão que exista além do estado colonial. Novamente, Chakraborty não encontra qual-

11-NE: Nissim está parcialmente errado. Embora nenhuma cena indique categoricamente as disparidades na propriedade de terra na aldeia, algumas poucas ocasiões são certamente sugestivas de tais disparidades.

12-Como Rustom Bharucha (1994, p. 803) aponta, "representantes da 'classe trabalhadora' ou dos 'destituídos' [...] foram quase sempre descritos nas narrativasmestre do cinema Híndi", mas "seus modos de representação têm sido artificiais, melodramáticos e exploradores".

Pensar a Prática, Goiânia, v. 15, n. 1, p. 1-271, jan./mar. 2012 
quer ausência nesta representação onde "estruturas decadentes de opressão indígena sejam apresentadas além do escopo dos subalternos" para o "limite da identidade dos camponeses ser fixada por meio das diversas condições de subordinação em que vivem e trabalham" (CHAKRABORTY, 2004, p. 559). Mais uma vez, ela conta com o argumento de Guha de que a resistência camponesa era caracterizada por uma "consciência negativa" que não "é poderosa o suficiente para que se esforcem pela liberação nacional". Ninguém argumenta que o filme deva apresentar tal esforço, mas se poderia esperar que o filme "subalterno", supostamente radical, apresentasse uma história diferente da realidade. O que pode ser solicitado é que o filme mostre alguma afinidade à história tal como aconteceu. Mas o que acontece é a mutilação da história, para além do seu reconhecimento, como se pode ver, por exemplo, na abordagem da rebelião de 1921 de Awadh.

Conforme documenta o historiador subalterno Pandey (1982, p. 171, 179-180), foi "quando o senhor de terras decidiu inserir novos e opressores impostos em um período de dificuldade considerável para setores importantes do campesinato que a resistência foi retomada em Awadh como algo moralmente certo e necessário" (grifo do autor). Portanto, foi a decisão dos proprietários de inserir novos impostos que não permitiam punição e que estivessem acima do que o estado britânico tinha imposto que levou os camponeses à revolta. Mais importante: a rebelião mostrou a habilidade dos camponeses de identificar seus "inimigos". Os pequenos moradores e os trabalhadores agrícolas atacaram os "taluqdars [...] pequenos proprietários, grandes cultivadores e, até mesmo, castas superiores em geral". Também culparam comerciantes, ourives e tecelões por explorar a situação e obter muitos lucros: "Houve também uma grande sensação de antagonismo em relação aos europeus e ao abuso de policiais ao desertar compatriotas e servir à raça estrangeira."

Essa rebelião, na verdade, não é a primeira a ocorrer na Índia colonial. Como o estudo de Guha demonstra, de 1783 (mesmo depois que os britânicos estabeleceram sua real hegemonia) a 1900, havia, aproximadamente, "110 problemas agrários de diferentes formas e em escalas que vão de confusões locais a guerras disseminadas por diferentes regiões" (GUHA, 1983, p. 2-3). É claro que esses problemas não estavam ligados a qualquer consciência nacionalista, mas eles definitivamente não estavam limitados apenas ao ataque aos britânicos, mas também se estendiam aos seus colaboradores. Isso é o que Lagaan, um 
filme que supostamente atinge o projeto dos estudos subalternos, bloqueia em favor de um simples binarismo de nativos versus britânicos. Essa estratégia racial e binária reifica e essencializa as duas categorias e, no processo, elimina todos os outros marcadores de diferença, tais como classe, cultura, sexo. Como resultado, mesmo sem qualquer referência explícita à nação e ao nacionalismo (a usual retórica do cinema comercial recente), as políticas do críquete em Lagaan investiram num nacionalismo que é fortemente reminiscente do nacionalismo burguês da Índia de 1920 em diante. Argumentei anteriormente que essa é uma tentativa anacrônica e deliberada de nacionalizar o passado, pois nos anos 1890 (em que se passa o filme) não havia "nacionalismo indiano" como conhecemos hoje (ver MANNATHUKKAREN, 2001). Chakraborty (2003, p. 1881) acredita erroneamente que desde então não há "referência evidente a nação ou a terra natal", não existe nacionalismo no filme. De acordo com ela,

o nacionalismo no críquete é exibido como temporário e provisório e, assim, diferente da política nacionalista, que é linear e evolucionista. Seria, então, anacrônico ler a especificidade (local e contextual) do passado ficcional exibido em Lagaan em termos do presente, quando o críquete se tornou um "instrumento para mobilizar sentimentos nacionais". (CHAKRABORTY, 2004, p. 558)

Chakraborty não observa que é exatamente isto o que o filme se propõe a mostrar, a transposição da grande popularidade do jogo e suas associações (particularmente exacerbadas) com o nacionalismo cultural no presente (MANNATHUKKAREN, 2001) ${ }^{13}$, em outro período

13-Os argumentos de Chakraborty são contraditórios de diversas maneiras. No final do ensaio, depois de todas as suas críticas contra a leitura do filme em termos do presente, onde o críquete é fortemente associado ao nacionalismo, ela argumenta que a vitória dos jogadores fictícios de Lagaan é um testemunho à qualidade dos moradores de Champaner e, de acordo com que as argumentações das leituras nacionalistas do filme argumentariam, à qualidade dos cidadãos da Índia. Além disso, ela afirma que o "jogo de críquete no filme diverte, pois reflete os desejos dos espectadores de que o time da vila de Chamapaner e assim, o seu time indiano, vencerá outros times estrangeiros [não só os britânicos]". Mais uma vez confirmando a estratégia de racialização e binarização detectada por mim em Lagaan, Chakraborty argumenta que o sucesso fenomenal do filme em ambos os círculos de elite e 
da história. É estranho que a leitura subalterna de Chakraborty queira renegar esse anacronismo, mesmo quando Dipesh Chakrabarty, proeminente historiador subalterno, também identifica um "anacronismo deliberado" em Lagaan para transpor o "agressivo", "nacionalismo massivo mediatizado" do presente até os anos 1890. De acordo com ele, o filme "deliberadamente mistura a cronologia histórica e utiliza a natureza massiva e espetacular do críquete - agora estabelecido nos anos 1890 - como uma metáfora visual para o nacionalismo anti-colonial indiano [...] cuja ênfase do jogo no filme, como num dia de críquete, é ganhar" (CHAKRABARTY, 2004, p. 341-342) ${ }^{14}$.

Chakraborty, que já argumentou sobre a restauração da agência do camponês e sobre a necessidade de reconhecer que os "moradores da vila são inteligentes o suficiente para reconhecer seus opressores do momento", agora abandona essa agência ao argumentar que "decantes estruturas de opressão indígena" estão "além do escopo dos subalternos" já que a consciência insurgente é sempre uma "consciência negativa". Essa é uma interpretação seletiva do trabalho de Guha. A opinião de Guha é a de que a consciência do povo era fragmentada e sem poder suficiente para desenvolver um movimento de liberação nacional. Mas a consciência negativa não era um obstáculo para identificar os opressores nativos e estrangeiros e preparar uma resistência violenta contra eles, como Guha e Pandey mostraram. Uma lei-

subalternos é porque os indianos (e outras nações pós-coloniais) "obtém tal prazer da vitória contra o Ocidente", o que representa para esses a passagem da sua autoestima aos seus jogadores de críquete, esperando que eles sejam "cidadãos ideais" (CHAKRABORTY, 2004, p. 565-566). A natureza ideológica do nacionalismo e do seu papel na obtenção do consentimento daqueles sob governo não é mencionada de forma alguma aqui por Chakraborty. Isso também vai contra seu argumento na versão anterior do ensaio: "para ler Lagaan como uma mitologia do nacionalismo [...] é necessário considerar todas as formas de movimentos de oposição, incluindo o nacionalismo indiano, como um projeto linear evolutivo" (CHAKRABORTY, 1995, p. 1883).

14-A atual confiança sobre os espetáculos televisivos do críquete emerge claramente das palavras do diretor de Lagaan, Ashutosh Gowarikar: "Nós queríamos proporcionar [ao filme] o sentimento de estar dentro de um estádio" (Rediff on the Net, 17 de Julho 2001, disponível no link: http://www.rediff.com/entertai/2001/jul/17ash.htm, acessado em 11 Nov. 2004).

Pensar a Prática, Goiânia, v. 15, n. 1, p. 1-271, jan./mar. 2012 
tura mais perspicaz de Guha teria mostrado que ele argumentou, apesar da negatividade, que a consciência do povo era desenvolvida o suficiente para identificar "alguns elementos básicos da exploração econômica e da superestrutura política que as legitima" (GUHA, 1983, p. 28).

Uma vez que a evidência história é esmagadora, Chakraborty, agora, não tem outra opção a não ser justificar a história do filme como um caso específico e não como representativo da tendência geral. Com isso, surge uma questão mais importante. De um vasto repertório de rebeliões camponesas e resistências a escolher, por que o cineasta escolheu um caso excepcional, em que todos os grupos nativos são afáveis e figuras positivas, e o Rajá local um nacionalista?

Essa pergunta não pode ser respondida pela hermenêutica textual de Chakraborty. Para isso, é preciso se afastar do texto para entender as estruturas materiais, ideológicas e institucionais que estão dialeticamente relacionadas. A autora argumenta que o questionamento dos camponeses apenas aos britânicos e não aos grupos dominantes nativos é um sinal de seus "modos improvisados e dinâmicos de agenciar a política dos camponeses"! A unidade de todos os grupos nativos no filme é apenas "contingente, provisória e contextual" e seria "ingênuo considerar as alianças anti-coloniais como permanentes e imutáveis" (CHAKRABORTY, 2003, p. 1883). Mas onde estão os exemplos de alianças anticoloniais na história, quando, na maioria das rebeliões e resistências, os camponeses atingiram os opressores nativos e os colaboradores de Rajás? Na rebelião de 1921, por exemplo, Gyanendra Pandey (1982, p. 179) indica que os moradores de castas superiores trabalharam abertamente contra a rebelião e também deram boas-vindas à ação policial contra os camponeses de casta inferior. Mesmo quando essas alianças anticoloniais ocorreram, elas tem se mostrado altamente vantajosas para os grupos dominantes. Em todo caso, os príncipes nativos e as classes dos senhores feudais eram opostas ao movimento nacional; as posições de poder deles tinham mais chance de sobrevivência na Índia britânica do que na Índia republicana (APPADURAI, 1995, p. 97) ${ }^{15}$.

O entusiasmo de Chakraborty pela aliança anticolonial representada no filme ignora as conclusões dos historiadores subalternos em seus

15-Obviamente, pode ter havido um pequeno número de príncipes propensos ao nacionalismo.

Pensar a Prática, Goiânia, v. 15, n. 1, p. 1-271, jan./mar. 2012 
trabalhos recentes: "Uma frente unida do povo indiano - senhores feudais e camponeses, donos de fábricas e trabalhadores manuais, príncipes feudais e pessoas pobres - em uma campanha anti-colonial era improvável: não houve esforço para obter mudanças nos locais que não atingiram tal unidade" (PANDEY, 1982, p. 187). Uma aliança anticolonial de todas as classes será frutífera apenas se estiverem de acordo com a hegemonia (no sentido de Gramsci) da maioria trabalhadora (ver: FORGACS, 1993). E envolveria, naturalmente, sacrifícios substanciais das castas e classes opressoras. Do contrário, resultaria numa forma de perpetuar a ordem social existente sem o colonizador. Pandey (1982) está absolutamente correto quando afirma que a "natureza [autônoma] do Swaraj ${ }^{16}$, que ocorreu a partir [da luta anti-colonial] dependeria muito da 'unidade' que foi forjada". Portanto,

a insistência do Congresso [...] em uma frente unida de senhores de terras, bem como camponeses e outros, foi uma declaração em favor do status quo e contra qualquer mudança radical na definição social quando os britânicos finalmente tomaram o reinado de poder [...] [Foi também] uma declaração contra a democracia participativa de massa e favorável à ideia de 'administração' - os senhores de terras e príncipes atuaram como fiduciários na esfera econômica, Gandhi e a empresa na política. (PANDEY, 1982, p. 187-188) $)^{17}$

16-NR: Na língua híndi, Swaraj quer dizer autogoverno; autonomia. No contexto da luta anticolonial indiana, a palavra foi mobilizada e utilizada por Gandhi, um dos principais e mais reconhecidos líderes da luta pela independência do país, para descrever um governo livre do domínio estrangeiro.

17-Dipesh Chakraborty (2004) argumenta que o nacionalismo do críquete retratado em Lagaan não é gandiano, mas um nacionalismo de massa mediatizado do presente que tem o único propósito de ganhar. O nacionalismo gandiano sempre defendeu o "propósito de ser bom acima e além da questão de ganhar ou perder" (p. 342). Embora eu concorde com Chakraborty de que o nacionalismo gandiano não foi apegado ao resultado final, ela ignora de forma crucial o fato de que ambos os nacionalismos são de caráter burguês (com variações pouco significativas). Recusando-se a olhar para a natureza de classe do nacionalismo, o ensaio de Chakraborty exemplifica a "virada cultural" de estudos subalternos posteriores e sua redenção parcial de líderes nacionalistas, como Gandhi.

Pensar a Prática, Goiânia, v. 15, n. 1, p. 1-271, jan./mar. 2012 
Em Lagaan, o debate sobre a natureza da aliança não se coloca em tudo; para que isso aconteça, a função exploradora e parasitária dos opressores nativos tem de ser reconhecida, e isso não acontece. Chakraborty só pode defender este nacionalismo burguês por evocar outra interpretação para a qual não há base no filme em si: o herói camponês "indica a possibilidade de lutar contra o administrador local, se necessário for, em um futuro indeterminado" (CHAKRABORTY, 2004, p. $558)^{18}$.

\section{Casta, classe e capital no críquete indiano}

De acordo com Chakraborty, "a contribuição mais importante de Lagaan para a cultura popular é sua habilidade para representar, de forma convincente, como os improvisos culturais dos grupos subalternos podem cooptar e criticar as formas principais e o tropos do Ocidente" (CHAKRABORTY, 2004, p. 560). Isso acontece porque o herói do filme afirma que o críquete é apenas uma cópia simples do antigo jogo de crianças, gilli-danda. Essa imitação inverte a missão colonizadora de civilizar os nativos inocentes e também de "profanar a 'pureza' da origem do críquete" afirmada pelos britânicos. Com o "mimetismo", através da afirmação de similaridade entre os gilli-danda e a excelência dos nativos no jogo, "o assunto britânico, o suposto original [...] [se tornou] apenas uma cópia sofisticada" (CHAKRABORTY, 2004, p. 561). Todos os ideais vitorianos de esportividade, fair-play, a redução dos interesses individuais, lealdade etc., e a política britânica de inculcá-los nos nativos, por meio de jogos como o críquete, tornaram-se objetos de crítica no filme por meio do incompatível jogo de críquete, entre os moradores pobres da vila e os britânicos, realizado por um oficial arrogante. A bondade e a força de caráter dos camponeses apresentados no filme é um triunfo para as qualidades dos camponeses, não para os gentleman vitorianos. Por meio do "mimetismo" e

18-Ela também afirma que, "diante do sucesso de Lagaan nas bilheterias, não será surpresa assistirmos a uma continuação do filme com Bhuvan liderando os moradores em uma rebelião contra o governo local" (CHAKRABORTY, 1995, p. 1884). Mas o diretor de Lagaan afirma categoricamente: "Não tenho a intenção de me repetir. Não vou fazer outro filme histórico com certeza" (Rediff on the Net, 17 Julho de 2001, disponível em: http://www.rediff.com/entertai/2001/jul/17ash.htm, acessado em 11 Nov. 2004).

Pensar a Prática, Goiânia, v. 15, n. 1, p. 1-271, jan./mar. 2012 
da repetição, os camponeses não apenas copiam, mas subvertem e "des-vitorianizam" o esporte nacional do Reino Unido (CHAKRABORTY, 2004, p. 563-565).

Tudo que Chakraborty afirma sobre as inversões bakhtinianas que supostamente aparecem no filme é seriamente deficiente devido à ausência de qualquer referência ao contexto material e se torna apenas um ato simbólico. Porém, Marx (1978, p. 60) nos lembra que, "a arma da crítica não pode, certamente, suplantar a crítica das armas. A força material deve ser derrubada pela força material". Não há descolonização real a menos que as fundações simbólica e material do colonialismo sejam desenraizadas. Atualmente, uma "reversão dos termos e do tropos do discurso colonial", como Chakraborty afirma, é um luxo que a minoria privilegiada pode ter nas nações "pós-coloniais". Para perguntar uma questão relevante: quais são as chances de um dalit de uma família agricultora que não tem onde morar jogar em uma equipe nacional de críquete na Índia? Sendo provável que toda sua vida tenha girado em torno da questão da sobrevivência, a questão, em si, seria artificial. Um milhão de dalits trabalha como limpador de rua na Índia. Não é incomum ler reportagens sobre dalits sendo linchados, encontrados nus ou forçados a comer fezes. Em uma terra onde o trabalho escravo é ilegal, existem 40 milhões de trabalhadores escravos, dos quais uma grande maioria é dalit. No ano 2000, o número de crimes (apenas alguns registrados) contra dalits foi de 25.455 (MAYELL, 2004). Lagaan e o cinema comercial (com poucas exceções) não apresentam essa rígida e terrível realidade. Para confirmar, portanto, como Chakraborty o faz, que o cinema popular tem "a capacidade de empoderar as massas", é necessário, como Walter Benjamin argumentaria, estetizar a política e, por implicação, os conceitos de emancipação e libertação. O intocável mudo não "opina sobre as práticas e estratégias repressoras na história dos subalternos sobre a vitória" conforme Chakraborty (2004, p. 568) afirma; em vez disso, sua mudez é um reflexo da realidade dos dalits e sua inquestionável servidão apenas reforça essa realidade como "normal".

Argumentar meramente que o críquete é uma cópia pobre do gillidanda não significa nada. Isto tem de ser entendido articulado ao declínio drástico do gilli-danda e de todos os outros jogos, principalmente nas últimas duas décadas, quando o capital (indiano e multinacional) realmente inundou o jogo de críquete. Atualmente, nas áreas rurais, as pessoas são forçadas a jogar jogos tais como o críque- 
te, no qual elas têm pouca chance de ganhar devido à sua natureza elitista $^{19}$.

Se formos nos aprofundar na sociologia do críquete, o que surgirá por conta disso será sua natureza enraizada de casta. O jogo na Índia tem sido absurdamente dominado por bramânes. Dos anos 1960 aos anos 1990, as equipes indianas tinham uma média de seis bramânes, às vezes até nove! (ANAND, 2003), isso a despeito do fato dos brâmanes não constituírem mais de $4 \%$ da população indiana. Não é chocante observar que 8 dos 14 primeiros ministros da Índia pertenceram à casta dos bramânes, sendo que cada instituição da Índia é virtualmente dominada por ela. O que é chocante é que o "sucesso" que os bramânes têm obtido no críquete tenha ocorrido apesar das suas tradicionais injunções ritualísticas contra a poluição por toque, contra o trabalho físico e outras atividades. Como uma classe dominante "produtora de conhecimento", eles obviamente deixam as tarefas de trabalho manual pesado para as castas inferiores. Mas o domínio dos bramânes no jogo mais lucrativo e popular na Índia mostra como o "capital cultural" durante todos esses séculos foi produtivamente convertido. Esse é outro exemplo de mutação bem-sucedida dos bramânes do reino sagrado tradicional para o reino moderno secular (NIGAM, 2000). A antropóloga e historiadora do críquete Ramachandra Guha comenta que o "críquete como esporte sem contato físico foi uma atração para os bramânes. Além disso, para poder jogá-lo não é preciso ser fisicamente forte" (Apud. ANAND, 2003). Ashis Nandy (1989) também teorizou sobre a estreita relação entre as estruturas míticas da filosofia hindu (leia-se brâmane) e o críquete ${ }^{20}$.

Como as forças de mercado tornam público os jogos da elite, o críquete ainda mantém a fortaleza dos bramânes, apesar de tantas mudanças ${ }^{21}$. É altamente instrutivo que, enquanto nos Estados Unidos os

19-Em estados como Kerala, onde a paixão pelo futebol se compara aos níveis latino-americanos, o críquete emergiu como o esporte mais importante.

20-Mas a popularidade do jogo entre as massas não pode ser reduzida aos fatores culturais sobre os quais Nandy baseia seus argumentos. Também não explica a imensa popularidade do jogo em países não hindus, como o Paquistão e o Sri Lanka.

21-Mesmo em 2000, que é recente, existiam oito jogadores brâmanes, num time de 11 (ANAND, 2004).

Pensar a Prática, Goiânia, v. 15, n. 1, p. 1-271, jan./mar. 2012 
negros definam formas de arte tais como o jazz, além de esportes como o boxe e o basquete (penetrando até mesmo em esportes dominados por brancos, como o tênis e o golfe), na Índia, nenhum simples dalit jogador de críquete jogou na equipe nacional em seis décadas após a independência ${ }^{22}$. "O críquete e os valores promovidos por ele estão bem inseridos na hierarquia de nossa sociedade feudal e de casta. O críquete não os interrompeu" (SARDESAI, apud., ANAND, 2003). Portanto, o que é urgentemente necessário é a democratização do esporte em todos os setores em que a população indiana tenha chances iguais de participar dos jogos de alto nível. O que isso significa é que no contexto indiano o problema que precisa urgentemente de atenção não é o que Lagaan está tentando demonstrar na interpretação de Chakraborty - a "vernacularização e a indigenização do críquete colonial [e o rapto do] críquete das estruturas monolíticas dos ingleses" (CHAKRABORTY, 2004, p. 564). Aparentemente, a retirada do críquete das estruturas monolíticas do bramanismo é o que é necessário.

Há outra colonização que caracteriza o críquete indiano. É a colonização das e pelas forças do capital e também dos órgãos privados disfarçados de públicos. Desde a entrada do capital transnacional no críquete, o jogo foi crescentemente forçado a se adaptar a essas necessidades. Esse é um fenômeno que obviamente não está limitado à Índia. O surgimento da agora imensamente popular versão do jogo de apenas um dia, com roupas coloridas, bola branca e partidas à noite, foi um impacto direto, e já tinha distanciado o jogo para longe de suas amarras inglesas tradicionais e vitorianas. A comercialização está fazendo cada vez mais com que o críquete tenha formatos curtos, como 20/20. A Índia, maior mercado de críquete, tem suportado o principal peso dessa modificação. Portanto, o número de jogos de um dia que o país tem jogado (à custa das tradicionais partidas de cinco dias), é maior que o de outros países ${ }^{23}$. A liberalização da economia indiana

22-Vinod Kambli, que jogou para a Índia e é normalmente considerado um dalit, tecnicamente não pertence à casta planejada - uma categoria do governo que denota os dalits (ver ANAND, 2004).

23-O Conselho Internacional de Críquete (ICC) tem procurado evitar a "morte" das partidas de teste de críquete através da introdução de um número obrigatório desses tipos de partida realizadas todos os anos desde 2001.

Pensar a Prática, Goiânia, v. 15, n. 1, p. 1-271, jan./mar. 2012 
desde 1991 ajudou o processo de influência do capital sobre o críquete. Hoje, o críquete atua em relação simbiótica com outras indústrias. A televisão leva o jogo até as mais distantes regiões da Índia ${ }^{24}$. A popularidade do críquete é utilizada para vender bens de consumo, enfatizados por jogadores e produzidos por empresas multinacionais e indianas ${ }^{25}$. A entrada implacável de produtos de luxo em áreas rurais está criando simultaneamente novas vontades e desejos.

A tese de vernacularização ou indigenização do críquete que Chakraborty propõe abrange o processo de difusão do críquete na Índia de uma maneira unilateral: modernidade (colonial do Ocidente) na forma do críquete ser apropriado e consumido por uma sociedade "tradicional". Mas isto ignora o fato de que a Índia - por meio de suas estruturas de patrocínio comercial, apoio estatal e base de espectadores - está liderando a modernização do críquete no mundo (PRASAD, 1998). Portanto, é "possível falar sobre outra dinâmica começando de um jogo controlado pela Inglaterra e associado a um conjunto de valores vitorianos, até poder-se falar de processos de modernização [...] por meio do qual uma parte da 'inalterada' tradição inglesa foi apropriada pela modernidade” (PRASAD, 1998, p. 1021). O que Chakraborty ignora é o fato de que o críquete é uma exceção rara na arena esportiva internacional, pois é um jogo em que não ocidentais (principalmente sul-asiáticos) são dominantes em termos de tomada de decisão, de geração de receita, público e etc. Isso inverte as relações centro-periferia que existem em outros esportes ${ }^{26}$. Um dos principais motivos para is-

24-O mercado televisivo pode cada vez mais ser medido pelo fato de que os direitos das TVs para transmitir o críquete na Índia, vendidos por US\$ 2 milhões em 1998-1999, já estão sendo cotados em US\$ 75 milhões por ano, um aumento fenomenal de quase 40 vezes em cinco anos (ver JOSEPH, 2004).

25-O mercado indiano de consumo de bens duráveis vale cerca de 5 bilhões de dólares americanos (veja Koreans Top of the Heap for Consumer Durables. Economic Times, 8 outubro de 2004, disponível no link: http://economic-times.indiatimes.com/articleshow/msid-77626,prtpage-1.cms, acessado em 13 de novembro de 2004).

26-Para mais detalhes sobre o surgimento do críquete não ocidental, ver Gupta (2004). Esse domínio estende-se também à valorização dos jogadores. Jogadores de críquete indianos ganham mais do que suas contrapartes de outros lugares.

Pensar a Prática, Goiânia, v. 15, n. 1, p. 1-271, jan./mar. 2012

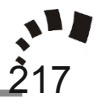


so é o declínio do jogo no país de sua origem, a Inglaterra (para uma análise convincente do fenômeno,ver MARQUSEE, 1994). Como Arjun Appadurai (1995, p. 107) afirma, no período atual os "impactos da mídia, da comercialização e da paixão nacional têm erodido quase completamente a velha civilidade associada ao críquete. O críquete hoje é agressivo, espetacular e frequentemente anti-esportivo, com audiências desejando a vitória nacional e jogadores e promotores querendo dinheiro".

Nas Antilhas, onde o críquete, às vezes, não é apenas um jogo, mas uma forma de afirmação contra os colonizadores, o jogo está em declínio terminal. Não pelo fato de as "estruturas monolíticas dos ingleses" terem sido reafirmadas, mas porque na era de comodificação do críquete, as pequenas nações caribenhas não podem gerar seu próprio capital doméstico para sustentar o jogo. Enquanto a juventude participa crescentemente de jogos dominados pelos Estados Unidos, tais como basquete, o que sobrou do críquete no Caribe é apropriado pelo capital transnacional, com sérias consequências para a sua estrutura doméstica (GUPTA, 2004, p. 258). A Índia, como uma das potências econômicas emergentes, evitará essa calamidade no críquete. Essa é uma conjuntura em que "o críquete subcontinental [é] um veículo ideal para corporações multinacionais que buscam penetrar nos 'mercados em ascensão', algo 'utilizado para vender produtos na Europa, América do Norte, Oriente Médio, Sudeste Asiático"'. Megaeventos como a Copa do Mundo se tornaram "um tipo de carnaval para a globalização - patrocinada por cigarros, refrigerantes e gigantes do cartão de crédito" (MARQUSEE, 1994, p. 265). A ênfase de Chakraborty na indigenização e descolonização (cultural) do críquete ignora essa realidade, na qual o jogo foi irreversivelmente capturado nos circuitos internacionais do capital, e a problemática pós-colonial do colonialismo (sem capitalismo), dificilmente pode nos fornecer as dicas para entendê$10^{27}$.

27-Isto não significa que a questão racial, que foi parte integrante do colonialismo, não é um problema no críquete internacional atualmente. O críquete inglês tem apresentado as piores manifestações de discriminação de brancos contra jogadores britânicos de cor. Existem também vários exemplos de abusos raciais de jogadores e da mídia branca contra jogadores de países "não brancos" (ver MARQUSEE, 1994). 
A agência para o críquete na Índia é a Comissão de Controle para o Críquete na Índia (BCCI - Board of Control for Cricket in India). Diferente de outros jogos na Índia, o críquete escapou das garras dos gigantes do Estado: a BCCI é um órgão privado com sua própria constituição, e o governo não interfere em seu funcionamento. Mas isso também significa que o público não exerce controle sobre o mais rico órgão de críquete no mundo ${ }^{28}$. Isso fez com que o esporte mais popular do país fosse raptado por um grupo de empresários e políticos que não têm qualquer experiência no jogo. A BCCI tem enfrentado acusações de mau comportamento e más práticas, as últimas acusações recaíram sobre direitos televisivos (ver JOSEPH, 2004). Uma discussão mais controversa ocorreu sobre o status "privado" da BC$\mathrm{CI}^{29}$. É provável que o Tribunal Superior de Justiça da Índia insista em instituir um mecanismo para garantir algum nível de responsabilidade pública. A oposição absoluta da BCCI a qualquer forma de controle de governo mostra, principalmente, não a preocupação para manter sua autonomia e eficiência, mas, sim, a vontade de evitar o escrutínio público a qualquer custo, independente de suas decisões afetarem um vasto setor do público que adora críquete.

A maior ironia é o fato de que apesar da imensa riqueza gerada, a BCCI retorna apenas uma pequena fração disso para o jogo e para o

28-No ano calendário de 2004-2005, o BCCI foi projetado para ganhar 96,5 milhões dólares americanos, enquanto os ganhos do ICC deveriam ser de apenas US \$ 76 milhões. Os ganhos do BCCI excluem a participação de 10\% dos lucros provenientes dos eventos realizados pelo ICC e também a participação de $40 \%$ cento na renda gerada por conselhos estaduais do cricket, através da venda de ingressos (BCCI has the Highest Strike Rate, Economic Times, 8 de setembro de 2004 disponível no link http://economictimes.indiatimes.com/articleshow/msid-853736, curpg-1.cms, acessado em 9 de novembro 2004).

29-O Supremo Tribunal de Deli já se pronunciou sobre o BCCI em um litígio de interesse público (PIL), uma vez que essa instituição desempenha funções públicas e também afirma representar a Índia. Assim sendo, entende o Supremo Tribunal de Deli que tem um dever para com o público e, portanto, está sujeito a escrutínio judicial. O PIL argumenta que, já que o BCCI recebe incentivos fiscais do governo e também concede terrenos para construção de estádios e etc, o Controlador e Auditor Geral da Índia deve ser a autoridade competente para auditar as finanças do BCCI. 
público que a ele assiste. O críquete da Índia é grosseiramente renegado em favor do críquete internacional. Na pior manifestação de divisão de classes, os subalternos que lotam os estádios estão sujeitos a um desconforto físico inimaginável. A maioria dos estádios de críquete no país é um "inferno" para os espectadores, e muitos deles não têm sequer facilidades como banheiros ${ }^{30}$. I. S. Bindra, ex-presidente da BCCI, disse que pessoas ficam "amontoadas como sardinhas" nos estádios. Elas não podem sequer sair de seus lugares para comprar uma garrafa de água, pois temem perder seus assentos. Isso depois de esperar até seis horas para entrar no estádio ${ }^{31}$. Chakraborty $(2004$, p. 550) observa que a "violência se tornou comum nos estádios de críquete em todo o país", mas parece inferior em relação ao "furor e à loucura patriótica", desconsiderando fatores como traumas físicos e violências corporais a que as massas estão sujeitas durante o jogo, o que atua como catalisador do mau comportamento.

Todos os fatores acima enfatizam o fato de o críquete não poder ser discutido em termos de descolonização (cultural) isoladamente, como a teoria pós-colonial o faz; as relações de dominação de casta e classe

30-O local onde acontece a partida de teste do Kanpur, Green Park, tem sido chamado de "o pior estádio de teste no mundo, antes e após o jogo". Um repórter do Indian Express escreveu: "As paredes do Green Park estão dilapidadas. O telhado de zinco no pavilhão principal está assustadoramente rachado. Os 60 banheiros em um estádio de 50.000 lugares sufocam com náuseas provocadas pelo cheiro. O painel e as telas de proteção de luz (sightscreens) são armações de metal simples. O grafite decora, se é que se pode usar esta palavra, as esquinas desertas do estádio". O estádio de Sardar Patel, em Ahmedabad, um ex-local de jogo teste, não tem instalações sanitárias (consulte India's Wicked Wicket Ways, Indian Express, 3 de agosto de 2003, disponível no link http://www.indianexpress. com/archive_full_story.php?content_id $1 \frac{1}{428820}$, acessado em 13 de novembro de 2004).

31-Bindra também admite que as instalações para o público são muito melhores em outros países do subcontinente (Clayton Murzello. We Owe It to The public, Says Bindra, Mid-Day, 18 de setembro de 2004, disponível no linkhttp://web.midday.com/sports/international/2004/september/92733.htm, acessado em 13 de novembro de 2004). No último jogo de um dia realizado no estádio Wankhede de Mumbai, um dos locais principais, os torcedores tiveram que esperar por 12 horas antes de a bilheteria abrir, tendo fechado após a venda de 5.000 ingressos, $80 \%$ dos 45.000 bilhetes.

Pensar a Prática, Goiânia, v. 15, n. 1, p. 1-271, jan./mar. 2012 
que estruturam o jogo atualmente devem ser observadas ${ }^{32}$. O críquete na Índia tem sido inextricavelmente relacionado aos circuitos globais do capital. É agora um instrumento para mobilizar "o sentimento nacional a serviço dos espetáculos transnacionais e da comodificação" (APPADURAI, 1995, p. 109). A forma com que a casta e a classe moldam o jogo é mais prejudicial para a democratização do jogo na Índia do que algumas "estruturas monolíticas dos ingleses", que foram desmanchadas há algum tempo. O críquete indiano mostra todas as características da lei de Trotsky sobre "desenvolvimento desigual e combinado do capitalismo", na qual uma minoria de jogadores, empresários e administradores prosperam ao explorar a maioria dos seguidores do críquete. Esses seguidores são reduzidos, literalmente, a "espectadores", sem qualquer controle sobre o jogo.

\section{O texto e seu contexto}

Uma compreensão do filme Lagaan não pode ser obtida ignorando o amplo contexto histórico e social no qual ele é produzido e recebido. Nesse contexto, as forças do capital global e do nacionalismo cultural são hegemônicas - um período que eu caracterizaria como capitalismo tardio e alto nacionalismo. A "hermenêutica textual" de Chakraborty não tem lugar para o contexto sócio-histórico e para as formas com que o texto fílmico é constituído por ele, ao mesmo tempo em que o constitui ${ }^{33}$. Desde a liberalização da economia indiana em 1991, a

32-Obviamente, as hierarquias de gênero são tão evidentes que o críquete feminino quase não tem popularidade.

33- No início, Chakraborty (2004) menciona que a entrada das classes subalternas na história através de "dispositivos de modernização", como o cinema e o críquete depende "do contexto histórico e social" (p. 551). Mas depois disso, não existe uma única tentativa para ligar o filme ao contexto sócio-histórico (os termos capitalismo ou capital, por exemplo, não aparecem sequer uma vez), reduzindo a afirmação inicial a uma banalidade. Da mesma forma, o autor afirma que o poder de um filme em descolonizar a mente "vai depender da afiliação, percepção, experiência etc., do observador" (p. 570). Mas não há explicação destas últimas condições no ensaio, relevando também uma forma de elitismo em que o teórico decide pelas massas sobre seus sentimentos. Sem qualquer tipo de evidência empírica, Chakraborty se assegura de que "o que encantou a massa indiana é o tema singular de $\mathrm{La}$ gaan: os desestabilizadores subalternos da história colonial do críquete" (p. 551).

Pensar a Prática, Goiânia, v. 15, n. 1, p. 1-271, jan./mar. 2012 
evolução do processo chamado de "aburguesamento das classes proprietárias da Índia" foi solidificado, "como efeito da expansão burguesa e sua confirmação política" (DESAI, 1999, p. 703). Enquanto isso tem contribuído para o surgimento da uma classe média significativamente grande, tem levado também à pauperização de grande parte da classe trabalhadora e de camponeses, afetando principalmente aqueles que estão em áreas rurais.

A economista Utsa Patnaik (2004) afirma que houve "declínio sem precedentes no poder de compra em áreas rurais", trazido pelo declínio do suporte estatal em gastos de desenvolvimento rural e com a redução das taxas de crescimento da agricultura. Portanto, em uma estatística chocante, a concentração dos grãos para 2000/2001 foi inferior aos anos anteriores à Segunda Guerra Mundial, que incluiu a escassez de comida em Bengali ${ }^{34}$. Nem é preciso dizer que esse declínio afetou ainda mais as áreas rurais onde os grãos constituem a principal comida. Os efeitos das políticas neoliberais influenciadas pelo sistema de Bretton Woods ${ }^{35}$ foram catastróficos para os camponeses de castas inferiores: a abertura do setor de sementes da Índia para empresas como Monsanto, Cargill e Syngenta, além de preços de equipamentos agrícolas em nível global, fizeram com que os camponeses perdessem US\$ 26 bilhões anualmente. Incapazes de pagar suas dívidas, mais de 25.000 fazendeiros cometeram suicídio desde 1997 (SHIVA, 2004).

Tal combinação criou uma grande mobilização das classes inferiores da sociedade indiana nos setores rurais e urbanos. Infelizmente, o descontentamento das classes foi direcionado a causas e movimentos que não ofereceram chances para suavizar suas condições. Assim, o movimento dos fazendeiros que surgiu na Índia é caracterizado por uma "celebração romântica da rusticidade autêntica, primitiva e harmoniosa 'Bharat' [nome nativo da Índia], em comparação com a pos-

34-A média per capita de absorção de grãos caiu de 177 kg por ano em 1991-1992, para $151 \mathrm{~kg}$ em 2000-2001 (PATNAIK, 2004).

35-NR: O chamado Sistema de Bretton Woods foi o resultado dos esforços para a criação de um gerenciamento econômico internacional. Após o término da Segunda Guerra Mundial, líderes dos países aliados assinaram durante Conferência Monetária e Financeira das Nações Unidas o chamado Acordo de Bretton Woods, que, entre outras coisas, criou as instituições financeiras que mais tarde se tornariam o Banco Mundial e o Fundo Monetário Internacional. 
sível ameaça da 'Índia' urbana e cultural” (DESAI, 1999, p. 704). A oposição na divisão urbano-rural encobre a divisão mais fundamental que existe entre as classes e as castas. A coalizão de diversas classes de fazendeiros na Índia desenvolvida a partir de noções de "comunidade moral" é inevitavelmente dirigida pelos interesses dos fazendeiros ricos (ver HARRIS, 1994; BRASS, 1991). Infelizmente, as políticas dos camponeses em Lagaan, ao invés de questionar essa estrutura de ofuscação de classe, replicaram-na.

Um tipo parecido de disfarce das contradições de classe como nos movimentos dos fazendeiros ocorre no desenvolvimento da "comunidade principal" - a nação. Se nacionalismos de Terceiro Mundo (mesmo a variedade burguesa) eram caracterizados pelo elemento mais importante, o anti-imperialismo, os atuais são definidos pela total subordinação ao imperialismo (DESAI, 2004). Desai afirma que isso é o surgimento do nacionalismo cultural, especialmente na Ásia. Enquanto todos os nacionalismos têm um componente cultural, os nacionalismos culturais são diferenciados dos primeiros nacionalismos desenvolvimentistas que emergiram das lutas anticoloniais populares, e que por isso tinham uma aparência de conteúdo igualitário. Mas, conforme eles se aproximam do nacionalismo cultural, "os elementos culturais populares tendem a se apropriar, conter ou, nos casos mais radicais, serem excluídos ou destruídos por elementos dominantes. Retirado também de seu projeto desenvolvimentista focado no futuro, o que se reafirmou largamente foi a ordenação hierárquica focada no passado da cultura nacional" (DESAI, 2004, p. 97). O nacionalismo hindu na Índia é um exemplo típico disso: foi completamente alinhado ao capital global, ao mesmo tempo em que buscava um projeto nacional atávico majoritário. Desde a decisão do governo indiano de se confrontar e lutar com o Paquistão, houve um surgimento sem precedentes na manifestação do jingoísmo ${ }^{36}$ como paradigma de patriotismo. E a cultura comercial foi inundada com produtos que expõem tal conteúdo ${ }^{37}$. Enquanto Lagaan não exibe tal jingoísmo (e também o

36-NR: Jingoísmo é uma doutrina nacionalista belicosa e extremista.

37-Há uma enorme quantidade de filmes "patrióticos" lançados em Bollywood nos últimos anos. Gadar: Ek Prem Katha, Maa Tujhe Salaam, LOC, Bharat Bhagya Vidhata, Sarfarosh, Indian, Ek Hindustani, Hindustan ki Kasam, Mission Kashmir, Border são alguns dos filmes que induziram um novo caminho, pois eles explicita- 
inimigo se torna o inglês, em vez do paquistanês), ele está definitivamente imbuído com um agressivo nacionalismo racial cujo único objetivo é a vitória. A ascensão do nacionalismo agressivo no final dos anos 1990 tem de ser localizada no contexto da ênfase do governo nacionalista hindu sobre a agenda de garantir o status de "grande poder" no mundo, recuperando a glória da civilização hindu daí em diante. A solução nacionalista de Lagaan sobre a questão dos camponeses é muito parecida com a tentativa do nacionalismo cultural de fornecer uma solução cultural para aumentar a segmentação econômica em relação à globalização ${ }^{38}$. Como Aijaz Ahmad (1992, p. 107-108) afirma, "qualquer tipo de nacionalismo que é constituído apenas pela 'experiência do colonialismo e imperialismo' [é, no fim das contas], excluído dos sistemas modernos de produção (capitalismo e socialismo)".

Chakraborty (2004, p. 568) afirma que Lagaan conscientiza os espectadores (por meio da "unidade do vilarejo e da incorporação de normas estrangeiras") do "passado unificado da luta por liberdade". Nós pensaríamos que um filme "subalterno" deve questionar esta unidade, considerando que esse objetivo foi alcançado por meio da supressão das demandas legítimas de casta, classe e gênero, e esta mesma unidade foi realizada nas "reformas de terras" burguesas em 1950 que ignoraram completamente os direitos dos camponeses pobres e dos trabalhadores agrícolas sem terras (dos quais uma maioria predominante é dalit).

Chakraborty não acha estranho o fato de que a unidade da luta pela liberdade esteja sendo invocada por um "filme camponês", mesmo depois de seis décadas governada pelo que Pranab Bardhan (1991) caracterizou como a aliança de classes proprietárias dominantes constituídas pela classe capitalista industrial e a classe agrária rica. Ela não questiona o fato de que o filme invoque esta unidade em uma épo-

mente denominam o Paquistão como inimigo (Ziya us Salam. Peddling Patriotism, The Hindu, 15 de março de 2002).

38-O alívio da pobreza foi colocado em quinto lugar na prioridade da agenda estabelecida pelo governo BJP. Durante o seu mandato, o Índice de Desenvolvimento Humano (IDH) da Índia caiu de 124 para127 (Nissim Mannathukkaren. Riding the Secular Rath, Outlook Web, 6 de maio de 2004, disponível no

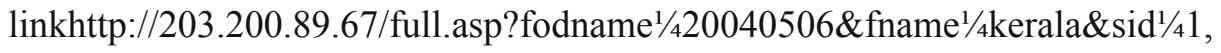
acessado em 10 de outubro de 2004).

Pensar a Prática, Goiânia, v. 15, n. 1, p. 1-271, jan./mar. 2012 
ca em que comunidades camponesas estão sendo destruídas devido à incursão de capital internacional que atua em colaboração com as classes proprietárias nativas. O nacionalismo que emerge no filme compara o nacionalismo atual na Índia com a maioria das nações póscoloniais. Essa consciência nacional, nas palavras proféticas de Frantz Fanon (1995, p. 156), "ao invés de ser a cristalização do desejo mais íntimo de todo povo, ao invés de ser o resultado imediato e óbvio da mobilização das pessoas [...] será apenas uma estrutura vazia, rígida e frágil do que deveria ter sido". A teoria pós-colonial, ao focar apenas na dominação cultural do Ocidente à custa de todas as outras formas de exploração, termina por ser cúmplice na transmissão desse nacionalismo hegemônico da elite.

O filme tem de ser compreendido não apenas em relação ao contexto sócio-histórico e social, mas também no contexto linguístico, que aqui significa a linguagem do cinema comercial popular na Índia. Claro que o cinema comercial (ou de entretenimento), não "reproduz simplesmente a ideologia capitalista patriarcal sem problemas" (DYER, 1993, p. 273), ou o nacionalismo, ou qualquer outra ideologia dominante. Mas o quanto um filme comercial resiste a eles depende da capacidade do filme de "contradizer as premissas de sua produção por meio de sinais de oposição, que podem questionar radicalmente o conteúdo da construção em geral" (BHARUCHA, 1994a, p. 801-2). Lagaan, como afirmei, não fornece tais sinais de oposição. Ao afirmar que o cinema comercial popular é um "reflexo das 'preocupações' e 'desejos' do público", Chakraborty não apenas cede ao reducionismo, mas ignora, muito problematicamente, os aspectos ideológicos inerentes ao entretenimento de massas (CHAKRABORTY, 2004, p. 567). ${ }^{39}$ Com certeza, a utopia - o poder de imaginar e visualizar uma realidade melhor - é um componente central do entretenimento. Mas ela bloqueia o fato de que "enquanto o entretenimento está respondendo às necessidades que são reais, ele também está definindo e delimitando o que constitui a necessidade legítima das pessoas nessa sociedade". Normalmente, essas necessidades estão relacionadas à classe, à raça e ao gênero (DYER, 1993, p. 278). No contexto indiano, é preciso inserir a casta nesta lista. $\mathrm{O}$ fato de um filme xenofóbico como Gadar ter

39-Chakraborty, como vimos, acredita que apenas a presença de castas mais baixas e mulheres (em posição marginalizada) no filme, indica estratégias e práticas repressivas.

Pensar a Prática, Goiânia, v. 15, n. 1, p. 1-271, jan./mar. 2012 
sido o mais ofensivo da última década ${ }^{40}$ mostra o quanto a ideologia do nacionalismo regressivo tem se tornado uma parte importante do entretenimento (embora isso não queira dizer que seu sucesso possa se reduzir a apenas um fator). Aqui, há intriga entre o Estado e o mercado na "fabricação do consentimento" (BHARUCHA, 1994b, p. 1390) para um nacionalismo reacionário.

No contexto do argumento de Chakraborty sobre o cinema popular, seria instrutivo pensar um pouco sobre o papel do cinema popular no estado indiano de Tamil Nadu. Como é amplamente conhecido, provavelmente nenhuma sociedade em qualquer lugar tenha visto tal impacto do cinema popular sobre sua política e cultura. O Estado já teve muitos ministros que eram semideuses da indústria cinematográfica, porém, nenhum mais famoso que M. G. Ramachandran (popularmente conhecido como MGR). Analisando o "fenômeno MGR", o historiador subalterno M. S. S. Pandian (1989, p. 62) fala brilhantemente dos processos por meio dos quais as elites governantes produzem o consentimento das classes subalternas. Diferente do que é apresentado em Lagaan, os filmes de MGR mostram um universo de relações de poder desiguais. Os exploradores são os senhores de terras, agiotas, camponeses ricos, industriais, racistas e assim por diante. Naturalmente, as vítimas são os donos de terras pobres, as castas inferiores, trabalhadores explorados, analfabetos e mulheres indefesas: "o poder é visto como penetrante, onipotente e indiferenciado enquanto suas vítimas são sempre dóceis, maltratadas e homogêneas em relação aos seus sofrimentos". Mas os subalternos têm esperança; eles têm o invencível MGR entre eles. No desafio do sistema social semifeudal dos vilarejos exibidos nos filmes, MGR, como herói, está constantemente se apropriando e subvertendo os três importantes sinais de autoridade: “(a) a autoridade para dispensar a justiça e exercer violência, (b) acesso à educação e (c) acesso às mulheres" (p. 63). Atos heróicos de MGR eram modelados de acordo com as canções folclóricas e baladas populares entre os pobres e as castas inferiores. Mas há uma distinção crucial entre as baladas e os filmes, que é a carência de um conteúdo progressista. Por fim, nos filmes de MGR, o protagonista subalterno

40-Gadar arrecadou, em rúpias indianas, cerca de US\$ 15 milhões nas bilheterias, mais que o dobro do valor arrecadado por Lagaan. Gadar está colocado em $11^{\circ}$ lugar na lista de maiores arrecadações de todos os tempos (ver http:// www.ibosnetwork.com/default.asp, acessado em 9 de novembro de 2004).

Pensar a Prática, Goiânia, v. 15, n. 1, p. 1-271, jan./mar. 2012

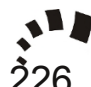


estabelece justiça, mas justiça dentro de um sistema, reafirmando, assim, o próprio sistema: "é um mundo de exploradores transformados com propriedades e relações de poder não transformadas" (p. 64-65). Nem é preciso dizer que em 11 anos como ministro-chefe, Tamil Nadu não obteve qualquer mudança na estrutura do sistema para o benefício das classes subalternas (p. 62). Este é um bom exemplo das formas com que o potencial crítico da cultura popular é apropriado pelas elites e pelas classes médias que são (primeiramente) os criadores do entretenimento de massa.

Sem um entendimento dialético da ideologia e da crítica como dois elementos da cultura de massa, a celebração unilateral de Chakraborty sobre Bollywood se degenera num populismo cultural que se vê como "crítica da modernidade" (ver NANDY, 1995, p. 235). Isso obscurece o fato de que a cultura comercial teve um papel importante no deslocamento à direita na política do mundo todo, inclusive na Índia. Como Simon During (1993, p. 18) afirma, "o populismo cultural requer uma análise muito nuançada das relações entre os mercados culturais e os produtos culturais, e entre a cultura e a política, para que possa, convincentemente, celebrar qualquer cultura popular como "progressista" A exclusão de Chakraborty da política e da economia não nos permite fazer isso.

\section{Conclusão}

Afirmei que a leitura subalterna do filme está repleta dos mesmos problemas e contradições que caracterizam o próprio projeto dos estudos subalternos. Por fim, ela segue a estrutura culturalista dos últimos estudos subalternos. De um compromisso de recuperar e documentar vozes subalternas, lentamente o projeto começa a se concentrar na crítica do "Iluminismo" ocidental e do eurocentrismo. A tendência onipresente da teoria pós-colonial de se concentrar apenas na descolonização (apenas em termos culturais) é visível no ensaio de Chakraborty (2003, p. 1882) (Lagaan menciona o "problema das nações pós-coloniais tentando resistir ao deslumbramento hegemônico do Ocidente"). Não faz perguntas sobre onde a descolonização (cultural) estaria na lista de prioridades para uma política programática nos países chamados de "pós-coloniais". Como Vinay Bahl (2000, p. 94) pergunta, "países não europeus, simplesmente por serem menos eurocêntricos, poderiam desfrutar de um estado de coisas felizes, apesar da 
globalização econômica e maior comunicação global". O foco sobre a cultura sem relações materiais resulta no consequente foco no eurocentrismo sem capitalismo. Essa obsessão com o eurocentrismo e com o colonialismo resulta numa evasão do presente. Como Dhareshwar (1995, p. 322) observa,

questões politicamente relevantes e intelectualmente desafiadoras sobre o Eurocentrismo podem ser encontradas em nossas relações com o presente pós-colonial. Sem a tematização deste relacionamento, a tentativa de provincializar a Europa pode, paradoxalmente, simplesmente nos enredar nessa província.

Enquanto Chakraborty é pega nessa armadilha do "Ocidente fantasmagórico" (DHARESHWAR, 1995, p. 322), a realidade é constituída pela hegemonia do que Vandana Shiva (2004) evocativamente chama de "feudalismo corporativo, a convergência mais desumana, brutal e exploradora do capitalismo corporativo global e do feudalismo local, em que o fazendeiro é vítima e se sente indefeso". Quando $40 \%$ da população rural da Índia têm uma alimentação como a da África subsasriana (PATNAIK, 2004), é difícil imaginar que filmes como Lagaan possam "empoderar as massas".

O voluntarismo que caracteriza a teoria pós-colonial é marcado aqui. No verdadeiro estilo dos estudos culturais, a ênfase está na agência de pessoas comuns, que satisfaz à resistência bakhtiniana por meio do "mimetismo irônico, inversão simbólica, abandono orgiástico, e até mesmo devaneios" (DURING, 1993, p. 11). Mas como Kumkum Sangari (1996, p. 464) afirma, "concepções de luta e agência transformadora, individual ou coletiva, são vazias sem um entendimento simultâneo de suas relações dialéticas com determinações materiais, epistêmicas, institucionais e das estruturas ideológicas com que eles se reproduzem e se transformam".

É claro que não há casos de formas cotidianas de resistência que não sejam uma parte inevitável da vida social subalterna. Mas para valorizá-los, quaisquer projetos de mudança social de longo prazo precisam participar na canalização de tais resistências para o princípio das relações hegemônicas de poder. A valorização da resistência cotidiana emerge no argumento de Chakraborty de que a imagem transmitida pelo filme "não é a da igualdade, mas a da sobrevivência e do sustento próprio" (CHAKRABORTY, 2004, p. 558). Por que, mesmo no século 
XXI, temos de lutar pela sobrevivência ao invés de sonhar com um futuro igualitário?

A indigenização do críquete representado em Lagaan apresenta "com sucesso as classes pobres e subordinadas em discussões sobre a modernidade e história" (CHAKRABORTY, 2004, p. 568). Mas não é perguntado sobre o porquê de um filme ser elogiado por ser um projeto dos estudos subalternos, que questiona os "principais textos e códigos" e "resiste ao término da história e aos gestos de possibilidades de outras perspectivas e histórias" (CHAKRABORTY, 2004, p. 569), não poder, de forma alguma, imaginar um dalit como herói depois de seis décadas de "descolonização". Depois de tudo, os dalits, a mais oprimida das comunidades, são os verdadeiros subalternos no contexto indiano. Por que um filme que supostamente reapresenta um "passado fictício" para "tentar reescrever o presente" (CHAKRABORTY, 2004, p. 569) não inclui a opressão de classe e de gênero como parte da realidade do presente? A resposta pode ser encontrada apenas fora dos parâmetros da hermenêutica textual, caminhando para fora do texto. No atual contexto sócio-histórico do capitalismo tardio e do alto nacionalismo, Lagaan é outra tentativa simbólica de apropriar, hegemonicamente, o subalterno ao imaginário da elite. Para parafrasear Walter Benjamin, o nacionalismo proporciona às massas o direito de se expressar, mas não o direito de mudar as relações de poder ou de propriedade.

\title{
Cricket and hindu nationalism in India: illusions of textual interpretation
}

\begin{abstract}
This paper will critique postcolonial theory's attempt to read the cricket nationalism portrayed in the Oscar-nominated Bollywood film Lagaan as one that subverts the civilizing mission of British colonialism and also restores the agency of the subaltern classes. Instead, it will argue that this cricket nationalism replicates Indian bourgeois nationalism, which has no place for the subaltern in its imaginary. It will also argue that the postcolonial thesis of decolonization and indigenization of cricket supposedly achieved by Lagaan is marked by a culturalism that does not take into account structural factors such as capital, class and caste that dominate the institution of cricket in India. Finally, against postcolonial theory's tendency to read a text in isolation from the context, it will be contended that the cricket nationalism of the film can only be understood by locating it in relation to the present socio-historic conjuncture wherein forces of capital and nationalism are hegemonic.
\end{abstract}

Keywords: Sport. Nationalism. History. India.

Pensar a Prática, Goiânia, v. 15, n. 1, p. 1-271, jan./mar. 2012

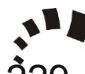




\section{Cricket y nacionalismo hindú en India: ilusiones de la interpretación textual}

\section{Resumen}

En este articulo crítica la lectura de la teoría post-colonial del nacionalismo en cricket representado en la película de Bollywood, Lagaan. Esta película se opone a la misión civilizadora del colonialismo británico y también restaura la agencia de las clases subalternas. Aparte de eso, este trabajo sostiene que el nacionalismo juega cricket en la India el nacionalismo burgués, que no hay lugar para el subordinado. También sostiene que la teoría post-colonial de la descolonización y la indigenización de cricket presuntamente llevado a cabo por Lagaan se caracteriza por un culturalismo que no tiene en cuenta los factores estructurales tales como el capital, la clase y la casta que dominan la institución de cricket en la India. Por último, en contra de la tendencia de la teoría post-colonial en la lectura de textos en forma aislada del contexto, se afirma que el nacionalismo de cricket en la película puede ser entendido mediante la localización de su relación con el supuesto actual, donde las fuerzas del capital y el nacionalismo son hegemónicos.

Palabras clave: Deporte. Nacionalismo. Historia. Índia.

\section{Referências}

AHMAD, A. Theory: Classes, Nations, Literatures. London: Verso, 1992.

ANAND, S. Eating With Our Fingers, Watching Hindi Cinema and Consuming Cricket. Himal, March 2002, Disponível em: http://www.himalmag.com/2002/march/essay.htm. Acesso em: 10 Nov. 2004.

. The Retreat of the Brahmin. Outlook, 10 Feb. 2003. Disponível em http://www.outlookindia.com/full.asp?fodna-

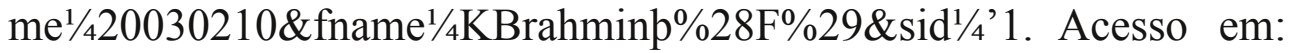
11 nov. 2004.

APPADURAI, A. Playing with Modernity: The Decolonization of Indian Cricket. In: APPADURAI, A. Modernity at Large. Minneapolis, MN: University of Minnesota Press, 1995.

BAHL, V. Situating and Rethinking Subaltern Studies for Writing Working Class History. In: DIRLIK, A.; BAHL, V.; GRAN, P. (eds.). History after the Three Worlds. Lanham, MD: Rowman \& Littlefield, 2000. 
BANNERJI, H. Projects of Hegemony. Economic and Political Weekly, 11 March, 2000.

BARDHAN, P. Dominant Proprietary Classes and India's Democracy. In: KOHLI, A. (ed.). India's Democracy: An Analysis of Changing State-Society Relations. New Delhi: Orient Longman, 1991, p. 214-224.

BENJAMIN, W. Illuminations. New York: Harcourt, 1955.

BHARUCHA, R. Utopia in Bollywood. Economic and Political Weekly, 15 April 1994a.

. On the Border of Fascism: The Manufacture of Consent in Roja. Economic and Political Weekly, 4 June 1994b.

BRASS, T. Moral Economies, Subalterns, New Social Movements and the (Re-) Emergence of a (Post-)Modernised Middle Peasant. Journal of Peasant Studies, vol. 18, 1991.

CHAKRABARTY, D. Radical Histories and Question of Enlightenment Rationalism. Economic and Political Weekly, 8 April 1995.

. The Fall and Rise of Indian Sports History. The International Journal of the History of Sport, vol. 21, issue 3/4, June-Sept. 2004.

CHAKRABORTY, C. Subaltern Studies, Bollywood and Lagaan. Economic and Political Weekly, 10 May 2003.

. Bollywood Motifs. The International Journal of the History of Sport, vol. 21, issue 3/4, p. 549-572, June-Sept. 2004.

CHATTERJEE, P. The Nation and its Fragments: Colonial and Postcolonial Histories. Princeton, NJ: Princeton University Press, 1993.

Democracy and Civil Society In: FAHIMUL, Q.; LELE, J. (eds.). Democracy and Civil Society in Asia. vol. 1. New York: Palgrave Macmillan, 2004. 
DESAI, R. Culturalism and Contemporary Right: Indian Bourgeoisie and Political Hindutva. Economic and Political Weekly, 20 March 1999.

. Nation Against Democracy: The Rise of Cultural Nationalism in Asia. In: FAHIMUL, Q.; LELE, J. (eds.). Democracy and Civil Society in Asia. vol. 1. New York: Palgrave Macmillan, 2004.

DEWS, P. The Logic of Disintegration. London: Verso, 1987.

DHARESSHWAR, V. Our Time: History, Sovereignty and Politics. Economic and Political Weekly, 11 de fevereiro 1995, 322

DIRLIK, A. The Postcolonial Aura. Boulder. CO: Westview Press, 1997.

DURING, S. Introduction. In: DURING, S. (ed.). The Cultural Studies Reader. London and New York: Routledge, 1993.

DYER, R. Entertainment and Utopia. In: DURING, S. (ed.). The Cultural Studies Reader. London and New York: Routledge, 1993.

FANON, F. National Culture. In: ASCROFT, B.; GRIFFITHS, G.; TIFFIN, H. (eds.). The Post-Colonial Studies Reader. London: Routledge, 1995.

FORGACS, D. National-Popular: Genealogy of a Concept. In: DURING, S. (ed.). The Cultural Studies Reader. London and New York: Routledge, 1993.

GUHA, R. Subaltern and Bhadralok Studies. Economic and Political Weekly, 19 Aug.1995, p. 20-57.

GUHA, R. Elementary Aspects of Peasant Insurgency in Colonial India. Delhi: Oxford University Press, 1983.

. On Some Aspects of the Historiography of Colonial India. In: GUHA, R. (ed.). Subaltern Studies I. Delhi: Oxford University Press, 1982.

GUPTA, A. The Globalization of Cricket: The Rise of the Non-West. 
The International Journal of the History of Sport, vol. 21, issue 2, p. 257-276, March 2004.

HARRISS, J. Between Economism and Post-Modernism. In: BOOTH, D. (ed.). Rethinking Social Development: Theory, Practice and Research. London: Longman, 1994.

ILAIAH, K. Productive Labour, Consciousness and History. In: AMIM, S.; CHAKRABARTY, D. (eds.). Subaltern Studies IX. De1hi: Oxford University Press, 1997. Lele, Jayant. Hindutva. Madras: Earthworm Books, 1995.

JOSEPH, M. Sachin Doesn't Play for India. Indiatimes, 15 de outubro de 2004. Disponível em: khttp://cricket.india- times.com/articleshow/msid-851406,curpg-2.cms. Acesso em 12 Nov. 2004.

LELE, J. Hindutva. Madras: Earthworm Books, 1995.

MANNATHUKKAREN, N. Subalterns, Cricket and the Nation: The Silences of "Lagaan". Economic and Political Weekly, 8 Dec. 2001.

MARQUSEE, M. Anyone But England: Cricket and the National Malaise. London: Verso, 1994.

MARX, K. Contribution to the Critique of Hegel's Philosophy of Right: Introduction. In: TUCKER, R. (ed.). The Marx-Engels Reader. New York: W.W. Norton \& Co., 1978.

MAYELL, H. India's 'Untouchables' Face Violence, Discrimination. National Geographic News, 02 de junho de 2003. Disponível em: http://news.nationalgeographic.com/news/2003/06/ 0602_030602_untouchables.html. Acesso em 11 nov. 2004.

NANDY, A. The Savage Freud and Other Essays on Possible and Retrievable Selves. Princeton, NJ: Princeton University Press, 1995.

. The Tao of Cricket. NewYork: Viking, 1989.

NIGAM, A. Secularism, Modernity, Nation: Epistemology of the Dalit Critique. Economic and Political Weekly, 5 nov. 2000. 
O'HANLON, R.; WASHBROOK, D. After Orientalism: Culture, Criticism, and Politics in the Third World. Comparative Studies in Society and History, vol. 34, n. 1, January 1992.

PANDEY, G. Peasant Revolt and Indian Nationalism. In: GUHA, R. (ed.). Subaltern Studies 1. Delhi: Oxford University Press, 1982.

PANDIAN, M.S.S. Culture and Subaltern Consciousness: An Aspect of MGR Phenomenon. Economic and Political Weekly, 29 de julho de 1989.

PATNAIK, U. Rural India in Ruins. Frontline, vol. 21, issue 5, 28 Feb.-12 March 2004.

PRASAD, M. M. Public Modernity: Some Issues. Economic and Political Weekly, 2 de maio de 1998.

SANGARI, K. Consent, Agency, and Rhetorics of Incitement. In: SATHYAMURTHY, T. V. (ed.). Social Change and Political Discourse in India: Structures of Power, Movements of Resistance. Vol. 3. Delhi: Oxford University Press, 1996.

SATHYAMURTHY, T.V. Indian Peasant Historiography. Journal of Peasant Studies, vol. 18, issue 1, 1990.

SHIVA, V. The Suicide Economy of Corporate Globalisation. Znet, 05 de abril de 2004, Disponível em: http://www.countercurrents.org/gloshiva050404.htm. Acesso em 14 nov. 2004.

Recebido em: 21/10/2011

Revisado em: 30/11/2011

Aprovado em: 02/02/2012

Endereço para correspondência

nmannathukkaren@dal.ca

Nissim Mannathukkaren

Dalhousie University

Halifax, Nova Scotia

Canada B3H 4R2

1.902.494.2211 